\title{
Efek Ekstrak Etanolik Jamur Kuping pada Performa Pertumbuhan dan Morfologi Usus Halus Ayam Jawa Super
}

\author{
(EFFECT OF ETHANOLIC EXTRACT OF WOOD EAR MUSHROOM \\ ON GROWTH PERFORMANCE AND SMALL INTESTINE MORPHOLOGY \\ OF JAWA SUPER CHICKEN) \\ Hilizza Awalina Zulfa ${ }^{1}$, Desy Safira ${ }^{1}$, \\ Tianti Arum Mawarni ${ }^{1}$, Hendry Tri Sakti Gunawan Saragih ${ }^{2}$ \\ ${ }^{1}$ Mahasiswa Fakultas Biologi, \\ ${ }^{2}$ Laboratorium Struktur dan Perkembangan Hewan \\ Fakultas Biologi, Universitas Gadjah Mada, \\ Jl. Teknika Selatan, Sekip Utara, Yogyakarta, Indonesia 55281 \\ E-mail: saragihendry@ugm.ac.id
}

\begin{abstract}
ABSTRAK
Penelitian ini bertujuan untuk mengetahui pengaruh ekstrak etanolik jamur kuping (Auricularia auricula) )yang diimbuhkan pada pakan terhadap performa pertumbuhan dan morfologi usus halus ayam jawa super [Gallus gallus gallus (Linnaeus, 1758)]. Penelitian ini menggunakan desain rancangan acak lengkap, terdiri atas lima perlakuan, dengan 20 ekor Day-old Chicks (DOC) pada masing-masing perlakuan sebagai ulangan. Perlakuan kontrol dengan pakan basal, perlakuan P1 dengan pemberian tambahan 1,25 g ekstrak etanolik A. auricula/kg dalam pakan basal, perlakuan P2 dengan 2,5 g ekstrak etanolik $A$. auricula/kg pakan basal, perlakuan P3 dengan 5 g ekstrak etanolik A. auricula/kg pakan basal, dan perlakuan P4 dengan 7,5 g ekstrak etanolik A. auricula/kg pakan basal. Pakan diberikan hingga umur 15 hari. Parameter yang diamati meliputi berat badan ayam pada umur pascamenetas 3,7 , 12, dan 15 hari, Feed Conversion Ratio (FCR) serta ketinggian villi, kedalaman kripta dan rasio villi/kripta usus halus di umur ayam ke-0 dan 15 hari. Analisis data dilakukan dengan uji sidik ragam satu arah dan dilanjutkan dengan uji Tukey dengan signifikansi $\mathrm{P} \leq 0,05$. Hasil penelitian menunjukkan bahwa berat badan, capaian berat badan, asupan pakan, nilai FCR dan morfologi usus halus pada ayam jawa super pada perlakuan P3 dan perlakuan P4 pada hari ke-15 lebih tinggi dibandingkan dengan kontrol dan perlakuan lainnya $(\mathrm{P} \leq 0,05)$. Simpulan dari penelitian menunjukkan bahwa ekstrak etanolik A. auricula dapat memberikan pengaruh baik terhadap performa pertumbuhan dan morfologi usus halus ayam jawa super.
\end{abstract}

Kata-kata kunci: ayam jawa super; ekstrak etanolik Auricularia auricula; capaian berat badan; FCR; usus halus

\begin{abstract}
This study was aim to determine the effect of ethanolic extract of wood ear mushroom (Auricularia auricula) on pre-starter feed against the growth performance and small intestine morphology of Jawa Super chicken [Gallus gallus gallus (Linnaeus, 1758)]. This study used a complete randomized design of five treatments with 20 Jawa Super day-old chicks (DOC) in each group as a replication. The control group used basal feed, group P1 supplemented with $1.25 \mathrm{~g}$ ethanolic extract of Auricularia auricula/kg of basal feed, group P2 with 2.5 g ethanolic extract of $A$. auricula $/ \mathrm{kg}$ of basal feed, group P3 with $5 \mathrm{~g}$ ethanolic extract of $A$. auricula $/ \mathrm{kg}$ of basal feed, and group $\mathrm{P} 4$ with $7.5 \mathrm{~g}$ ethanolic extract of $A$. auricula $/ \mathrm{kg}$ of basal feed. The feed was given until the age of 15 days. The parameters observed in this study: chicken weight at age of posthatch, 3, 7, 12, and 15 days, Feed Conversion Ratio (FCR), as well as villus height, crypt depth and villus/crypt ratio of small intestine, at the chicken age of posthatch and 15 days. The result showed that growth performance and histology structure of small intestine in Jawa Super chicken in P3 and P4 group on the 15th day were higher compared to those in the control group and other treatment groups $(\mathrm{P} \leq 0.05)$. The conclusion of the study showed that the ethanolic extract of $A$. auricula with at a dose of $5 \mathrm{~g} / \mathrm{kg}$ and $7.5 \mathrm{~g} / \mathrm{kg}$ of basal feed can increase the growth performance, villus height, crypt depth and villus/crypt ratio in the Jawa Super chicken.
\end{abstract}

Keywords: Jawa Super chicken; ethanolic extract of Auricularia auricula; weight gain; FCR; small intestine 


\section{PENDAHULUAN}

Usaha budidaya ayam dapat dipakai sebagai pendukung program kecukupan daging nasional dan sekaligus untuk meningkatkan kesejahteraan pelaku usaha, baik sebagai peternak, perusahaan penyedia produksi ternak, dan pedagang ayam. Pada budidaya ayam, hal yang penting diperhatikan yaitu persentase biaya pakan terhadap biaya sarana produksi ternak (sapronak) (Suwarta, 2010). Umumnya, salah satu faktor penting dalam industri peternakan ayam adalah ketersediaan pakan (Mastuti dkk., 2018). Nilai Feed Convertion Ratio (FCR) merupakan perbandingan antara jumlah pakan yang digunakan dengan jumlah penambahan bobot ayam yang dihasilkan (Suwarta, 2010).

Pemberian pakan terhadap ayam ternak di era saat ini selalu berupaya mendapatkan performa terbaik yang dapat dihasilkan. Salah satu cara yang digunakan untuk meningkatkan performa dari ayam ternak adalah dengan memberikan zat aditif pada pakan yang diberikan. Menurut Association of American Feed Control Officials (AMFCO) dalam buku panduan yang dikeluarkan oleh Food and Agriculture/FAO (2001), suatu zat dapat ditambahkan dalam jumlah tertentu pada pakan basal untuk memenuhi kebutuhan yang diinginkan. Zat aditif tersebut dapat berupa nutrisi tambahan seperti suplemen nutrisi berupa vitamin, mineral, atau zat prebiotik, dan enzim. Salah satu tanaman herbal yang dapat dijadikan feed additive adalah ekstrak etanolik jamur kuping (Auricularia Auricula).

Kandungan dari ekstrak etanolik jamur kuping (Auricularia Auricula) yaitu alkaloid, polifenol, thiamin, riboflavin, asam askorbat, vitamin D2 dan mineral (Salas et al., 2016; Acharya et al., 2004). Senyawa yang berperan sebagai antibakteri dan antioksidan, yaitu senyawa alkaloid dan polifenol. Alkaloid dapat mencegah pertumbuhan beberapa bakteri yang berbahaya bagi saluran pencernaan, serta mengganggu proses penyerapan nutrien (Naseri et al., 2012; Acharya et al., 2004), sedangkan senyawa polifenol berperan sebagai antimikroba dan antioksidan (Rajput et al., 2013).

Perkembangan saluran pencernaan memiliki peran yang penting dalam tahap awal pertumbuhan ayam (Nir et al., 1996), terutama pada proses pencernaan dan penyerapan yang terjadi di usus halus. Usus halus mempunyai peranan penting dalam penyerapan dan transfer nutrien. Semakin baik respons usus halus pada ayam semakin baik pula pertumbuhan ayam tersebut yang dapat dilihat dari struktur histologi usus halusnya (Novel et al., 2009). Berdasarkan beberapa penelitian yang telah dilakukan, salah satu parameter yang dapat digunakan untuk menilai baik atau tidaknya pertumbuhan ayam adalah dengan menilai kualitas maupun ukuran organ dalam seperti struktur histologi usus halus (Wang et al., 2011). Kemampuan pencernaan dan penyerapan dipengaruhi juga oleh tinggi dan luas permukaan vili usus halus serta kedalaman kripta usus halus (Wang et al., 2008). Penelitian ini dilakukan bertujuan untuk mengetahui pengaruh pemberian ekstrak etanolik jamur kuping (A. auricula) pada pakan basal terhadap performa pertumbuhan dan morfologi usus halus ayam jawa super [Gallus gallus gallus (Linnaeus, 1758)].

\section{METODE PENELITIAN}

Penelitian menggunakan 100 ekor day-old chicks (DOC) ayam jawa super yang dipelihara secara intensif dalam kandang selama 15 hari dan dibagi menjadi lima perlakuan yang masingmasing terdiri atas 20 ekor DOC. Perlakuan tersebut adalah sebagai berikut: Kontrol (0 g ekstrak etanolik $A$. auricula/kg pakan basal), Perlakuan 1 (1,25 g ekstrak etanolik $A$. auricula/kg pakan basal), Perlakuan 2 (2,5 g ekstrak etanolik $A$. auricula/kg pakan basal), Perlakuan 3 (5 g ekstrak etanolik A. auriculal kg pakan basal), dan Perlakuan 4 (7,5 g ekstrak etanolik $A$. auricula/kg pakan basal).

Terhadap DOC dilakukan proses aklimatisasi selama tiga hari, agar ayam melakukan penyesuaian terhadap lingkungannya. Pakan diberikan secara ad libitum dua kali sehari, yaitu pagi dan sore hari. Ayam divaksinasi melalui tetes mata kanan dengan vaksin tetelo atau New Castle Disease (Medivac ND Hitcner B $1^{\circledR}$, Medion, Bandung, Indonesia) pada umur empat hari. Penimbangan berat badan ayam dilakukan pada umur pascamenetas 3, 7 dan 15 hari.

Jumlah pakan yang diberikan dihitung setiap harinya hingga 15 hari. Rasio konversi pakan (Feed Conversion Ratio/FCR) diukur dengan menghitung jumlah pakan per kilo gram yang dibutuhkan (Feed Intake/FI) untuk menambah berat badan per kilo gramnya (Weight Gain/WG). Sebanyak tiga ekor ayam dari setiap perlakuan dikorbankan nyawanya 
dengan cara dieutanasi pada pascamenetas serta pada umur 15 hari. Selanjutnya ayam dibedah dan diambil duodenum serta jejunumnya kemudian difiksasi ke dalam larutan Bouin selama 12 jam. Kemudian dilakukan pencucian organ dari larutan Bouin menggunakan alkohol 70\% hingga warna kuning Bouin berkurang. Selanjutnya dilakukan proses pembuatan sediaan histologi dengan metode paraffin dan pewarnaan hematoxylin eosin (HE). Preparat diamati di bawah mikroskop cahaya serta dicari villi dan kriptanya dengan lensa objektif 10 kali. Dokumentasi pengamatan diambil menggunakan aplikasi dan kamera digital mikroskop AmScope. Kemudian ketinggian villi serta kedalaman kripta diukur menggunakan aplikasi Miconos Image Raster 3 (Samanya dan Yamauchi, 2001). Rasio villi/kripta dihitung dari $=$. [Rata-rata tinggi villi $(\mu \mathrm{m})] \mathrm{x}$ [rata-rata kedalaman kripta $(\mu \mathrm{m})]^{-1}$. Data perkembangan berat badan ayam, ketinggian villi serta kedalaman kripta dan rasio villi/kripta usus halus yang telah diperoleh dianalisis menggunakan analisis sidik ragam satu arah dan dilanjutkan uji Tukey dengan signifikansi $P \leq 0,05$.

\section{HASIL DAN PEMBAHASAN}

\section{Performa Pertumbuhan Ayam Jawa Super}

Ekstrak etanolik jamur kuping yang ditambahkan pada pakan memberikan pengaruh positif terhadap performa pertumbuhan ayam jawa super diantaranya berat badan dan efisiensi pakan. Pada hasil berat badan ayam umur hari pascamenetas dan umur tiga hari tidak terdapat perbedaan yang signifikan $(P>0,05)$ pada semua perlakuan, sedangkan pada umur hari tujuh dan hari 12 , terdapat kenaikan berat badan dan perbedaan yang signifikan dengan rata-rata berat badan kontrol, P1 dan P2 lebih rendah dibandingkan kelompok P3 dan P4 $(P \leq 0,05)$. Pada umur hari ke-15, terdapat kenaikan grafik dan perbedaan yang signifikan dengan hasil pada P3 dan P4 yang lebih tinggi dibandingkan perlakuan lainnya. Penambahan berat badan mengalami kenaikan pada umur ayam umur 7-15 hari. Penambahan berat badan ini menandakan efisiensi absorbsi nutrien pada pencernaan ayam jawa super.

Pada capaian berat badan yaitu penambahan berat badan ayam per harinya, perlakuan P3 memiliki hasil tertinggi dibandingkan dengan perlakuan lainnya, sedangkan pada asupan pakan yaitu sisa pakan per ayam setiap harinya, P4 memiliki hasil tertinggi dibandingkan perlakuan lainnya.

Pada data FCR P3 lebih rendah dibandingkan P4 yang berarti P3 menunjukkan data yang lebih efisien. Menurut Suwarta (2010), FCR merupakan perbandingan antara asupan pakan dengan kenaikan berat badan ayam perharinya. Rendahnya nilai FCR menunjukkan, bahwa penambahan sejumlah pakan dapat menghasilkan penambahan berat badan ayam dengan proporsi yang lebih besar.

Nilai FCR ayam meningkat seiring dengan bertambahnya umur. Perbaikan FCR dan berat badan ini, mungkin dapat terjadi karena kemampuan kandungan jamur kuping ini tidak hanya mengandung polisakarida, tetapi ekstrak etanolik dari jamur ini juga mengandung alkaloid, polifenol, thiamin, riboflavin, asam askorbat, vitamin D2 dan mineral (Salas et al., 2016; Acharya et al., 2004). Senyawa alkaloid dapat mencegah pertumbuhan beberapa bakteri yang mengganggu proses penyerapan nutrien (Naseri et al., 2012; Acharya et al., 2004), sedangkan senyawa polifenol berperan sebagai antimikrob dan antioksidan (Rajput et al., 2013). Kelompok unggas/aves lebih menyukai pakan yang mengandung flavonoid. Pemberian asupan flavonoid setiap hari mampu meningkatkan kemampuan respons imun terhadap keberadaan antigen asing serta mengurangi stres oksidatif sehingga pakan yang dikonsumsi dan nutrien yang terserap dapat lebih efisien (Catoni et al., 2008). Performa pertumbuhan pada ayam jawa super meliputi penambahan berat badan dan nilai FCR menjadi semakin baik pada hari ke15 .

Hasil abrsorbsi nutrien pada pencernaan ayam yang berjalan dengan baik, ditandai dengan kenaikan berat badan pada ayam yang berbanding lurus dengan asupan pakan, serta nilai FCR yang rendah. Pada perlakuan P3 dan P4 menunjukan data performa pertumbuhan yang baik dibandingkan kontrol dan perlakuan lainnya. Hal ini menunjukan perlakuan P3 dengan dosis $5 \mathrm{~g}$ dan 7,5 g ekstrak etanolik $A$. auricula/kg pakan basal memiliki pengaruh paling besar terhadap performa pertumbuhan ayam jawa super.

\section{Morfologi Usus Halus Ayam Jawa Super \\ Sistem pencernaan yang baik mesti didukung dengan villi dan kripta yang memiliki morfologi yang baik, sehingga nutrien dapat}




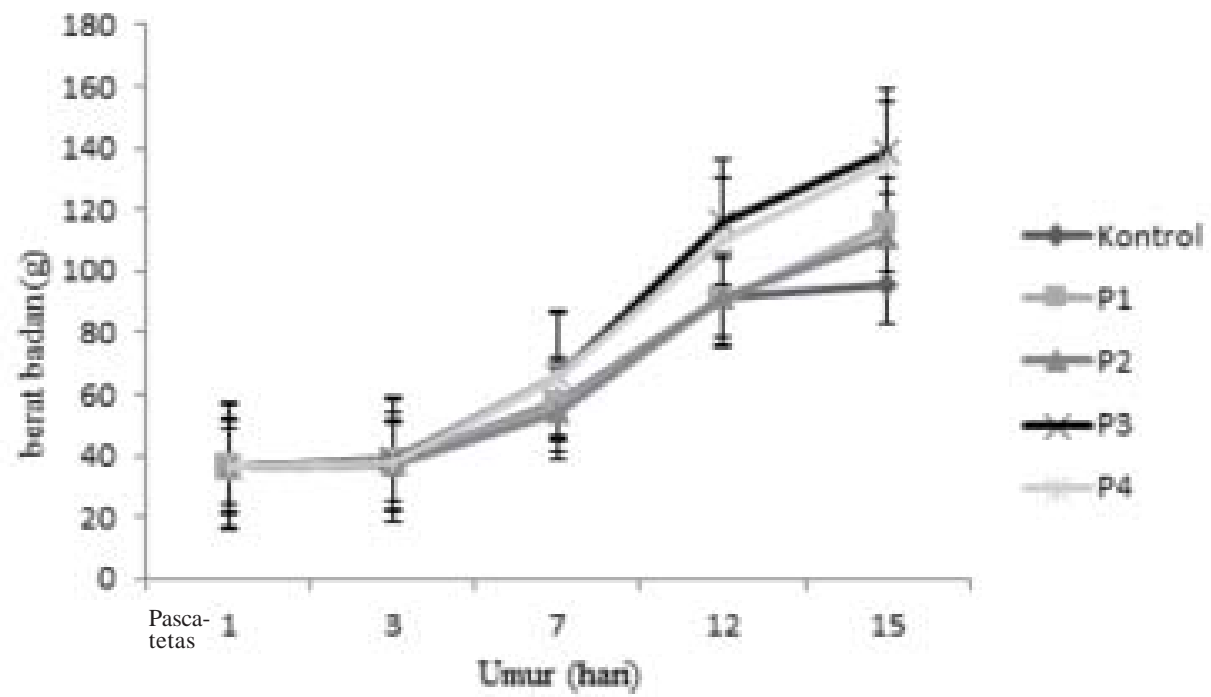

Gambar 1. Efek ekstrak etanolik A. auricula pada berat badan (g) ayam Jawa Super [Gallus gallus gallus (Linnaeus, 1758)]

Keterangan: kontrol (0 g ekstrak etanolik A auricula/kg pakan basal), P1= Perlakuan 1 (1,25 g ekstrak etanolik A. auricula/kg pakan basal), P2= Perlakuan 2 (2,5 g ekstrak etanolik A. auricula $/ \mathrm{kg}$ pakan basal), P3= Perlakuan 3 (5 g ekstrak etanolik A. auricula/kg pakan basal), dan P4= Perlakuan 4 (7,5 g ekstrak etanolik A. auricula/kg pakan basal).

Tabel 1. Efek ekstrak etanolik A. auricula pada performa pertumbuhan (Mean $\pm S D)$ ayam jawa Super [Gallus gallus gallus (Linnaeus, 1758)]

\begin{tabular}{|c|c|c|c|c|c|c|c|c|}
\hline \multirow[t]{3}{*}{ Variabel } & \multicolumn{7}{|c|}{ Perlakuan } & \multirow{3}{*}{ FCR (g:g) } \\
\hline & \multicolumn{5}{|c|}{ Berat Badan (g) } & \multirow{2}{*}{$\begin{array}{l}\text { Capaian } \\
\text { berat badan } \\
\text { (g/day) }\end{array}$} & \multirow{2}{*}{$\begin{array}{l}\text { Asupan } \\
\text { pakan } \\
(\mathrm{g} / \text { day })\end{array}$} & \\
\hline & Pasca menetas & Hari ke-3 & Hari ke-7 & Hari ke-12 & Hari ke-15 & & & \\
\hline introl & $36,63 \pm 3,16^{\text {ns }}$ & $38,25 \pm 4,10^{\text {ns }}$ & $57,25 \pm 6,34^{\mathrm{a}}$ & $91,0 \pm 12,25^{\mathrm{a}}$ & $95,5 \pm 37,35^{\mathrm{a}}$ & $7,75 \pm 1,16^{\mathrm{a}}$ & $12,00=$ & $1,55 \pm 0,84^{\mathrm{a}}$ \\
\hline P1 & $36,25 \pm 3,20^{\text {ns }}$ & $38,25 \pm 2,19^{\text {ns }}$ & $56,75 \pm 2,66^{\text {a }}$ & $90,25 \pm 8,92^{\mathrm{a}}$ & $115,25 \pm 13,33^{\mathrm{a}, \mathrm{b}, \mathrm{c}}$ & $9,13 \pm 1,36^{a, b}$ & $11,70 \pm 0,00^{\mathrm{a}}$ & $1,28 \pm 0,11^{\mathrm{a}, \mathrm{b}}$ \\
\hline P2 & $36,75 \pm 2,66^{\mathrm{ns}}$ & $36,88 \pm 3,56^{\text {ns }}$ & $53,75 \pm 4,98^{\mathrm{a}}$ & $91,13 \pm 9,05^{\mathrm{a}}$ & $110,63 \pm 9,81^{\mathrm{a}, \mathrm{b}}$ & $8,00 \pm 1,07^{\mathrm{a}}$ & $12,52 \pm 0,00^{\mathrm{d}}$ & $1,57 \pm 0,53^{\mathrm{a}}$ \\
\hline P3 & $36,25 \pm 1,49^{\text {ns }}$ & $38,75 \pm 4,27^{\mathrm{ns}}$ & $66,25 \pm 3,54^{b}$ & $115,75 \pm 6,92^{b}$ & $138,38 \pm 8,80^{c}$ & $10,50 \pm 0,53^{b}$ & $11,82 \pm 0,00^{b}$ & $1,13 \pm 0,48^{b}$ \\
\hline $\mathrm{P} 4$ & $36,75 \pm 3,53^{\text {ns }}$ & $38,13 \pm 3,52^{\text {ns }}$ & $66,25 \pm 3,81^{\mathrm{b}}$ & $110,25 \pm 4,50^{\mathrm{b}}$ & $135,5 \pm 25,28^{b, c}$ & $10,00 \pm 0,00^{\mathrm{b}}$ & $13,32 \pm 0,00^{\mathrm{e}}$ & $1,33 \pm 0,43^{\mathrm{a}, \mathrm{b}}$ \\
\hline
\end{tabular}

Keterangan: K= Kontrol (0 g ekstrak etanolik A. auricula/kg pakan basal), P1= Perlakuan 1 (1,25 g ekstrak etanolik $A$. auricula/kg pakan basal), P2= Perlakuan 2 (2,5 g ekstrak etanolik $A$. auricula/kg pakan basal), P3= Perlakuan 3 (5 g ekstrak etanolik $A$. auricula/kg pakan basal), dan P4= Perlakuan 4 (7,5 g ekstrak etanolik A. auricula/kg pakan basal).

a-e Perbedaan notasi pada nilai di baris yang sama menunjukkan perbedaan yang signifikan $P \leq 0,05$.

${ }^{\text {ns }}$ Nilai tidak berbeda secara signifikan $(P>0,05)$.

terabsorbsi dengan sempurna. Proses pencernaan ayam terjadi pada usus halus, seperti duodenum, jejunum dan ileum. Salah satu cara mengetahui struktur duodenum dan jejunum yang baik yaitu dengan mengukur ketinggian villi, kedalaman kripta dan rasio villi/kripta (rasio V/C). Ketinggian villi diukur dari ujung villi (lamina propria) hingga pangkalnya (pertemuan villi dan kripta), sedangkan untuk kedalaman kripta diukur dari pertemuan villi dan kripta hingga batas distal kripta. Tinggi villi berbanding lurus dengan kedalaman kripta dan berbanding lurus pula dengan tingkat efisiensi absorbsi nutrien pada pencernaan ayam. Tingginya villi dapat menyebabkan semakin tingginya tingkat efisiensi pakan 
ayam. Kedalaman kripta menunjukkan kecepatan perbaikan jaringan villi saat terjadi pengelupasan, peradangan, ataupun keberadaan racun yang diproduksi oleh patogen (Svihus, 2014; Rajput et al.,2013).

Hasil pengamatan terhadap ketinggian villi, kedalaman kripta dan perhitungan rasio V/C duodenum ditampilkan pada Tabel 2 yang dihitung pada ayam pascamenetas dan umur 15 hari. Pada pascamenetas belum terdapat hasil signifikan pada semua perlakuan. Hal ini karena proses penyerapan nutrien belum didukung oleh morfologi duodenum yang baik, dilihat dari umur ayam yang masih muda, sehingga proses tersebut belum terjadi secara sempurna. Pada umur 15 hari hasil perhitungan ketinggian villi, P3 dan P4 memiliki hasil tertinggi dibandingkan kelompok lainnya, sedangkan pada hasil perhitungan kedalaman kripta, P3 dan P4 juga yang memiliki hasil tertinggi dibandingkan perlakuan lainnya. Pada hasil perhitungan rasio v/c pada perlakuan P4 memiliki hasil terendah dibandingkan dengan perlakuan lainnya. Hasil rasio v/c ini menjadi salah satu parameter tingkat absorbsi nutrien, jika villi tinggi, maka diikuti oleh kripta yang dalam, dan menghasilkan rasio v/c rendah.

Pada Tabel 3 disajikan hasil pengukuran ketinggian villi, kedalaman kripta, dan rasio v/ c jejunum yang diukur pada ayam pascamenetas dan umur 15 hari. Pengukuran ketinggian villi, kedalaman kripta, dan rasio v/c pada jejunum ayam pascamenetas belum didapatkan hasil yang signifikan semua perlakuan. Hal ini karena proses penyerapan nutrien belum didukung oleh morfologi jejunum yang baik, dilihat dari umur ayam yang masih muda dan adanya proses aklimasi sehingga penyerapan nutrien belum terjadi secara optimal. Pada ayam umur 15 hari, pengukuran ketinggian villi, ayam-ayam yang mendapat perlakuan $5 \mathrm{~g}$ ekstrak etanolik $A$. auricula/kg pakan basal memiliki hasil tertinggi dibandingkan perlakuan lainnya, sedangkan pada hasil pengukuran kedalaman kripta, perlakuan $5 \mathrm{~g}$ ekstrak etanolik A. auricula/kg pakan basal juga memiliki hasil tertinggi dibandingkan kelompok lainnya. Pada hasil pengukuran rasio v/c, kelompok perlakuan $5 \mathrm{~g}$ ekstrak etanolik $A$. auricula/kg pakan basal memiliki hasil terendah dibandingkan dengan perlakuan lainnya. Pengukuran rasio v/c merupakan parameter pada absorpsi nutrien, jika hasil pegukuran vili tinggi maka diikuti oleh hasil pengukuran kripta yang dalam, serta menghasilkan rasio v/c yang rendah (Wu et al., 2004). Pada Gambar 2, disajikan struktur histologis jejunum dengan pewarnaan HE dan menggunakan lensa objektif 10 kali pada kontrol dan semua perlakuan, ternyata pada vili yang tinggi dan kedalaman kripte paling dalam terdapat pada kelompok perlakuan $5 \mathrm{~g}$ ekstrak etanolik $A$. auricula $/ \mathrm{kg}$ pakan basal.

Tabel 2. Efek ekstrak etanolik A. auricula pada ketinggian villi, kedalaman kripte, dan rasio villi/ kripte (Mean $\pm S D)$ duodenum ayam Jawa Super [Gallus gallus gallus (Linnaeus, 1758)] umur hari ke-0, 3, 7, 12, dan 15.

\begin{tabular}{lcccccc}
\hline \multirow{2}{*}{ Variabel } & \multicolumn{3}{c}{ Pasca menetas } & \multicolumn{3}{c}{ Hari ke-15 } \\
\cline { 2 - 7 } & $\begin{array}{c}\text { Ketinggian } \\
\text { villi }(\mu \mathrm{m})\end{array}$ & $\begin{array}{c}\text { Kedalaman } \\
\text { kripte }(\mu \mathrm{m})\end{array}$ & $\begin{array}{c}\text { Rasio } \\
\text { V/C }(\mu \mathrm{m})\end{array}$ & $\begin{array}{c}\text { Ketinggian } \\
\text { villi }(\mu \mathrm{m})\end{array}$ & $\begin{array}{c}\text { Kedalaman } \\
\text { kripte }(\mu \mathrm{m})\end{array}$ & $\begin{array}{c}\text { Rasio } \\
\text { V/C }(\mu \mathrm{m})\end{array}$ \\
\hline K & $69,40 \pm 14,88^{\text {ns }}$ & $15,60 \pm 1,14^{\text {ns }}$ & $3,8 \pm 1,10^{\text {ns }}$ & $97,64 \pm 6,18^{\mathrm{a}}$ & $20,0 \pm 3,46^{\mathrm{a}}$ & $4,60 \pm 1,00^{\mathrm{b}}$ \\
P1 & $69,60 \pm 12,60^{\text {ns }}$ & $15,80 \pm 1,64^{\text {ns }}$ & $3,8 \pm 0,84^{\text {ns }}$ & $96,56 \pm 5,50^{\mathrm{a}}$ & $19,68 \pm 3,76^{\mathrm{a}}$ & $4,40 \pm 0,96^{\mathrm{b}}$ \\
P2 & $68,80 \pm 12,34^{\text {ns }}$ & $17,00 \pm 1,73^{\text {ns }}$ & $3,4 \pm 0,90^{\text {ns }}$ & $104,40 \pm 3,10^{\mathrm{b}}$ & $15,73 \pm 3,04^{\mathrm{b}}$ & $2,84 \pm 0,80^{\mathrm{a}}$ \\
P3 & $68,60 \pm 10,14^{\text {ns }}$ & $18,00 \pm 2,00^{\text {ns }}$ & $3,2 \pm 0,45^{\text {ns }}$ & $107,60 \pm 1,80^{\mathrm{b}, \mathrm{c}}$ & $33,32 \pm 13,65^{\mathrm{b}}$ & $2,84 \pm 0,37^{\mathrm{a}}$ \\
P4 & $68,60 \pm 10,83^{\text {ns }}$ & $17,20 \pm 1,79^{\text {ns }}$ & $3,4 \pm 0,95^{\text {ns }}$ & $108.64 \pm 5.7^{\mathrm{c}}$ & $33,96 \pm 7,01^{\mathrm{b}}$ & $2,68 \pm 0,56^{\mathrm{a}}$ \\
\hline
\end{tabular}

Keterangan: K= Kontrol (0g ekstrak etanolik A. auricula/kg pakan basal), P1= Perlakuan 1 (1,25 g ekstrak etanolik $A$. auricula/kg pakan basal), P2= Perlakuan 2 (2,5 g ekstrak etanolik $A$. auricula/kg pakan basal), P3= Perlakuan 3 (5 g ekstrak etanolik $A$. auricula/kg pakan basal), dan $\mathrm{P} 4=$ Perlakuan 4 (7,5 g ekstrak etanolik $A$. auricula/kg pakan basal).

a-c Perbedaan notasi pada nilai di baris yang sama menunjukkan perbedaan yang signifikan $P \leq 0,05$.

${ }^{\mathrm{n} s}$ Nilai tidak berbeda secara signifikan $(P>0,05)$. 


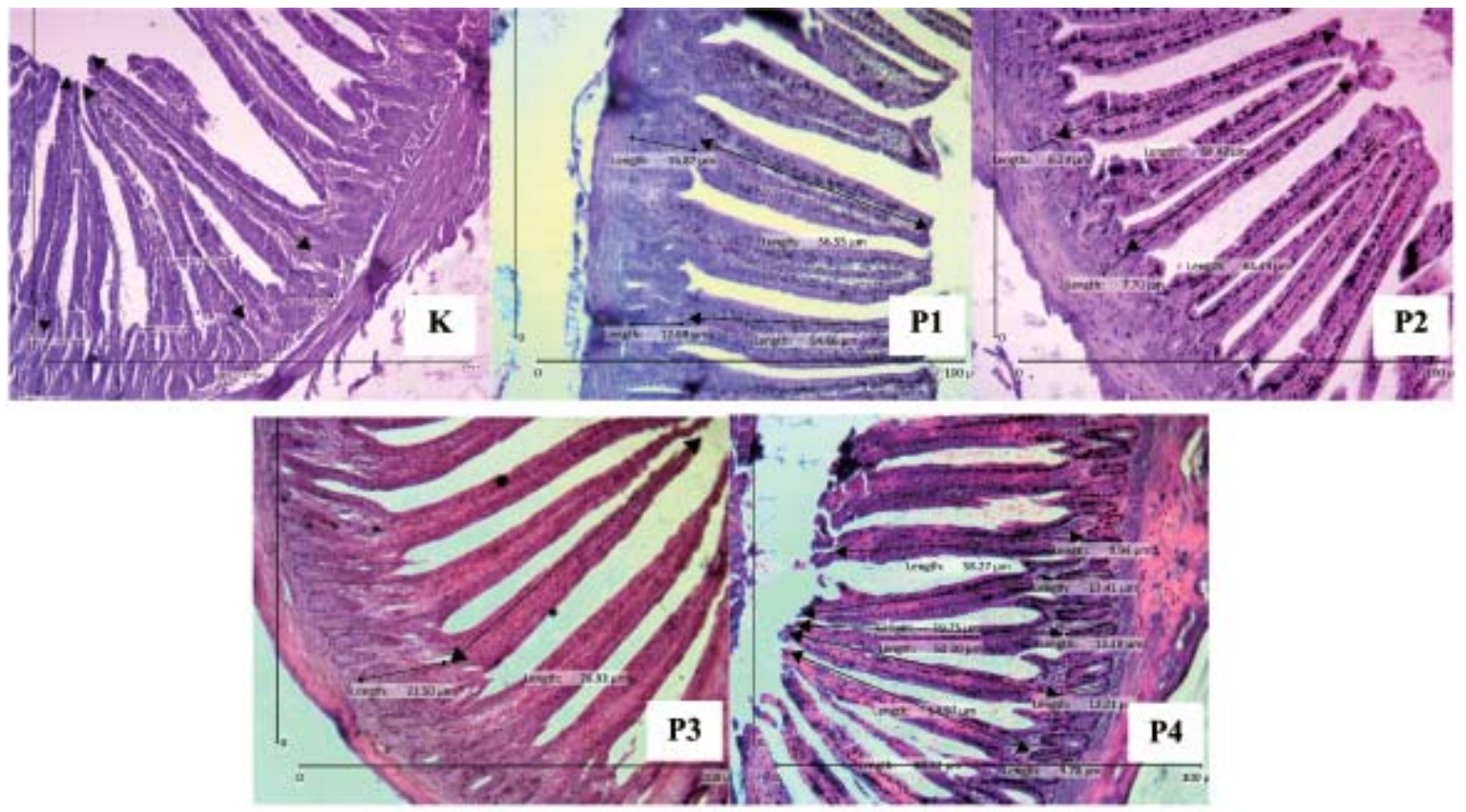

Gambar 2, Struktur histologi jejunum ayam Jawa Super umur 15 hari dengan lensa objektif 10 kali, pewarnaan HE, K= Kontrol (0g ekstrak etanolik A, auricula/kg pakan basal), $\mathrm{P} 1=$ Perlakuan 1 (1,25g ekstrak etanolik A, auricula/kg pakan basal), P2= Perlakuan 2 (2,5g ekstrak etanolik $A$, auricula/kg pakan basal), $\mathrm{P} 3=$ Perlakuan 3 (5g ekstrak etanolik $A$, auricula/kg pakan basal), dan $\mathrm{P} 4=$ Perlakuan 4 (7,5g ekstrak etanolik $A$, auricula/kg pakan basal).

Tabel 3. Efek ekstrak etanolik A. auricula pada ketinggian villi, kedalaman kripte, dan rasio villi/ kripte (Mean $\pm S D$ ) jejunum ayam Jawa Super [Gallus gallus gallus (Linnaeus, 1758)] umur pascamenetas, $3,7,12$, dan 15 hari.

\begin{tabular}{lcccccc}
\hline Variabel & \multicolumn{3}{c}{ Pasca menetas } & \multicolumn{3}{c}{ Hari ke-15 } \\
\cline { 2 - 7 } & $\begin{array}{c}\text { Ketinggian } \\
\text { villi }(\mu \mathrm{m})\end{array}$ & $\begin{array}{c}\text { Kedalaman } \\
\text { kripte }(\mu \mathrm{m})\end{array}$ & $\begin{array}{c}\text { Rasio } \\
\text { V/C }(\mu \mathrm{m})\end{array}$ & $\begin{array}{c}\text { Ketinggian } \\
\text { villi }(\mu \mathrm{m})\end{array}$ & $\begin{array}{c}\text { Kedalaman } \\
\text { kripte }(\mu \mathrm{m})\end{array}$ & $\begin{array}{c}\text { Rasio } \\
\text { V/C }(\mu \mathrm{m})\end{array}$ \\
\hline $\mathrm{K}$ & $38,63 \pm 1,81^{\mathrm{ns}}$ & $11,13 \pm 1,54^{\mathrm{ns}}$ & $3,53 \pm 0,61^{\mathrm{ns}}$ & $60,16 \pm 5,31^{\mathrm{b}}$ & $14,07 \pm 1,65^{\mathrm{b}}$ & $4,33 \pm 0,60^{\mathrm{a}}$ \\
P1 & $38,93 \pm 1,77^{\mathrm{ns}}$ & $10,36 \pm 3,00^{\mathrm{ns}}$ & $4,04 \pm 1,28^{\mathrm{ns}}$ & $56,02 \pm 5,29^{\mathrm{a}}$ & $12,70 \pm 1,90^{\mathrm{b}}$ & $4,50 \pm 0,88^{\mathrm{a}}$ \\
P2 & $36,94 \pm 2,09^{\mathrm{ns}}$ & $11,98 \pm 2,09^{\mathrm{ns}}$ & $3,19 \pm 0,81^{\mathrm{ns}}$ & $62,31 \pm 5,60^{\mathrm{b}}$ & $10,26 \pm 2,46^{\mathrm{a}}$ & $6,48 \pm 1,87^{\mathrm{b}}$ \\
$\mathrm{P} 3$ & $36,54 \pm 1,68^{\text {ns }}$ & $10,33 \pm 3,19^{\mathrm{ns}}$ & $3,76 \pm 0,90^{\mathrm{ns}}$ & $71,53 \pm 4,34^{\mathrm{c}}$ & $17,83 \pm 3,67^{\mathrm{c}}$ & $4,19 \pm 0,96^{\mathrm{a}}$ \\
P4 & $38,63 \pm 3,87^{\mathrm{ns}}$ & $9,86 \pm 1,32^{\mathrm{ns}}$ & $3,97 \pm 0,61^{\mathrm{ns}}$ & $55,06 \pm 4,89^{\mathrm{a}}$ & $12,19 \pm 1,80^{\mathrm{b}}$ & $4,63 \pm 0,90^{\mathrm{a}}$ \\
\hline
\end{tabular}

Keterangan: K= Kontrol (0g ekstrak etanolik A. auricula/kg pakan basal), P1= Perlakuan 1 (1,25 g ekstrak etanolik $A$. auricula/kg pakan basal), P2= Perlakuan 2 (2,5 g ekstrak etanolik $A$. auricula/kg pakan basal), P3= Perlakuan 3 (5 g ekstrak etanolik $A$. auricula/kg pakan basal), dan P4= Perlakuan 4 (7,5 g ekstrak etanolik $A$. auricula/kg pakan basal).

a-c Perbedaan notasi pada nilai di kolom yang sama menunjukkan perbedaan yang signifikan $P \leq 0,05$.

${ }^{\text {ns }}$ Nilai tidak berbeda secara signifikan $(P>0,05)$.

Hal ini tentunya berkaitan dengan penambahan bahan aditif berupa ekstrak etanolik jamur kuping pada pre-starter pakan basal ayam, yang berpengaruh pada jumlah kelenjar intestinal. Semakin banyak jumlah kelenjar intestinal, hal ini akan menunjang perkembangan sel epitel penyusun villi dan memengaruhi tinggi dari villi tersebut. Menurut Yamauchi (2002), kelenjar intestinal bermuara pada kripta yang terdapat pada villi 
intestinal, yang disusun oleh sel epitel silindris sebaris. Kelenjar ini menghasilkan mukus dan beberapa enzim untuk metabolisme peptida, lemak, karbohidrat, dan getah usus (mucin) yang berfungsi melindungi mukosa usus. Kelenjar intestinal berfungsi menunjang perkembangan sel epitel penyusun villi. Perkembangan sel epitel tersebut berasal dari kelenjar intestinal yang mengarah kepuncak villi melalui pergantian sel yang ditandai dengan adanya sel yang lepas dan masuk ke lumen. Proses pergantian sel epitel villi berlangsung secara berkesinambungan.

Berdasarkan hasil penelitian ini dapat dilihat bahwa villi yang paling tingg dan kripta duodenum yang paling dalam ditemukan pada P3 dan P4, dibandingkan kontrol dan perlakuan lain, sedangkan pada parameter V/C terendah yaitu pada kelompok P4. Menurut Wang dan Peng (2008), efisiensi penggunaan pakan peternakan unggas bergantung pada saluran pencernaan, utamanya pada morfologi villi dan kripta yang berperan penting dalam pencernaan nutrien dan asimilasi. Maka, semakin baik morfologi villi dan kripta yang dimiliki oleh saluran pencernaan pada ayam, maka penyerapan nutrien akan semakin baik dan efisien. Laudadio et al., (2012) menyatakan bahwa semakin tinggi villi, hal tersebut berbanding lurus dengan kedalaman kripta, maka luas daerah absorpsi nutrien akan semakin besar. Selain itu, kapasitas pencernaan dan absorpsi nutrien juga dapat diketahui dari rasio villi/kripta. Semakin besar rasio villi/kripta, maka semakin tinggi pula tingkat pencernaan dan absorpsi nutriennya. Tingkat pencernaan dan absorbsi nutrien pada ayam yang didukung oleh morfologi villi dan kripta, akan memengaruhi peningkatan performa pertumbuhan dan metabolisme.

Pengaruh ekstrak etanolik jamur kuping dalam pakan basal ayam ini berbanding lurus menunjang perkembangan sel epitel penyusun villi. Hal ini memberi pengaruh pada morfologi yaitu tinggi villi yang berbanding lurus dengan kedalaman kripta. Meningkatnya tinggi villi pada umur 15 hari menunjukkan bahwa pemberian ekstrak etanolik jamur kuping dapat meningkatkan luas permukaan duodenum sehingga usus dapat melakukan absorpsi makanan dengan lebih baik. Hal ini sesuai dengan pernyataan Adibmoradi et al. (2006), yang menyatakan bahwa berkurangnya tinggi villi atau pendangkalan kedalaman kripta dapat mengurangi proses absorpsi nutrien. Kamboh et al. (2015) juga menyatakan bahwa semakin rendah tinggi villi dan semakin dangkal dalam kripta dapat menyebabkan buruknya pertumbuhan ayam.

Ekstrak etanolik jamur kuping mengandung senyawa yang berperan sebagai antibakteri dan antioksidan, yaitu senyawa alkaloid dan polifenol. Alkaloid dapat mencegah pertumbuhan beberapa bakteri yang berbahaya bagi saluran pencernaan, serta mengganggu proses penyerapan nutrien (Naseri et al., 2012; Acharya et al., 2004), sedangkan senyawa polifenol berperan sebagai antimikrob dan antioksidan (Rajput et al.,2013). Senyawa yang terkandung dalam ekstrak etanolik jamur kuping ini berperan dalam memengaruhi morfologi villi dan kripta, yaitu meningkatkan tinggi villi dan memperdalam kedalaman kripta. Hal ini menunjukan bahwa P3 dengan dosis 5 g ekstrak etanolik $A$. auricula/kg pakan basal dan P4 dengan dosis 7,5 g ekstrak etanolik A.auricula per kilo gram pakan basal memiliki pengaruh paling besar terhadap morfologi duodenum dan jejunum ayam jawa super.

\section{SIMPULAN}

Dari hasil penelitian ini dapat disimpulkan yaitu pemberian stimulan berupa zat aditif ekstrak etanolik jamur kuping (A. auricula) dapat memperbaiki performa pertumbuhan dan struktur histologi duodenum serta jejunum ayam jawa super

\section{SARAN}

Perlu dilakukan penelitian lanjutan tentang senyawa murni pada jamur kuping (A. auricula) yang berperan penting dalam meningkatkan pertumbuhan ayam jawa super

\section{UCAPAN TERIMA KASIH}

Ucapan terima kasih disampaikan kepada Prof. Yuny Erwanto yang membantu menyediakan bibit ayam Jawa Super dan Hestu Widyatmoko, S.Pt., M.Sc. yang telah menyiapkan pakan basal 


\section{DAFTAR PUSTAKA}

Acharya K, Samui K, Rai M, Dutta B, Acharya R. 2004. Antioxidant and nitric oxide synthase activation properties of Auricularia auricula. Indian Journal of Experimental Biology 42: 538-540.

Adibmoradi M, Navidshad B, Seifdavati J, Royan M. 2006. Effect of dietary garlic meal on histological structure of small intestine in broiler chickens. The Journal of Poultry Science 43: 378-383.

Catoni C, Schaefer HM, Peters A. 2008. Fruit for health: the effect of flavonoids on humoral immune response and food selection in a frugivorous bird. Functional Ecology 22(4): 649-654.

FAO, 2001. FAO technical guidelines for responsible fisheries 5. FAO. Roma. Hlm. 47.

Kamboh AA, Arain MA, Mughal MJ, Zaman A, Arain ZM, Soomro AH. 2015. Flavonoids: health promoting phytochemicals for animalproduction. Journal of Animal Health and Production 3(1): 6-13.

Laudadio V, Passantino L, Perillo A, Lopresti G, Passantino A, Khan RU, Tufarelli V. 2012. Productive performannce and histological features of intestinal mucosa of broiler chickens fed different dietary protein levels. Poultry Science 91: 265-270.

Mastuti R, Supristiwendi, Andika. 2018. Pengaruh skala usaha, biaya pakan dan penggunaan tenaga kerja terhadap pendapatan peternak ayam broiler pedaging (Gallus Sp) di Kecamatan Idi Rayeuk Kabupaten Aceh Timur. Agrisamudra Jurnal Penelitian 5(1): 75-83.

Naseri KG, Rahimi S, Khaki P. 2012. Comparison of the effects of probiotic, organic acid and medicinal plant on campylobacter jejuni challenged broiler chickens. Journal of Agriculture Science and Technology 14: 1485-1496.

Nir I, Nistan ZEA, Dunnington P, Siegel PB. 1996. Aspects of food intake restriction in domestic fowl: metabolic and genetic considerations. Worlds Poultry Science Journal 52: 251-266.
Novel DJ, Ng'ambi JW, Norris D, Mbajiorgu CA. 2009. Effect of different feed restriction regimes during the starter stage on productivity and carcass characteristics of male and female ross 308 broiler chickens. Journal Poultry Science 8(1): 35-39.

Rajput N, Muhammad N, Yan R, Zhong X, Wang T. 2013. Effect of dietary supplementation of curcumin on growth performannce, intestinal morphology and nutrients utilization of broiler chicks. Journal of Poultry Science 50(1): 44-52.

Suwarta. 2010. Efektifitas pola kemitraan inti plasma dan produktivitas, usaha ternak ayam broiler plasma dan mandiri serta faktor yang mempengaruhi di kabupaten sleman. Jurnal-Program Studi Ekonomi Pertanian UGM 4(1): 256-232.

Salas RCD, Orden EA, Orden MEM. 2016. Productivity and financial viability of commercial broiler farm using climate controlled system: the case in a state-owned university in Nueva Ecija, Philippines. Journal of Science and Technology 1(1): 3245.

Samanya M. Yamauchi K. 2001. Morphological changes of the intestinal villi in chickens fed the dietary charcoal powder including wood vinegar compounds. Journal of Poultry Science 38: 289-301.

Svihus B. 2014. Function of the digestive system. Journal of Application Poultry Research 23: 306-314.

Wang JP, Yan L, Lee JH, Zhou TX, Kim IH. 2011. Effects of dietary delta-aminolevulinic acid and vitamin $\mathrm{c}$ on growth performance, immune rgan weight, and ferrum status in broiler chicks. Livestock Science 135: 148152.

Wang H, Gao Y, Shih CH. 2008. Effects of dietary supplementation of keratinase on growth performance, nitrogen retention and intestinal morphology of broiler chickens fed diets with soybean and cottonseed meals. Animal Feed Science and Technology 140: 376-384.

Wang JX, Peng KM. 2008. Developmental morphology of the small intestine of African ostrich chicks. Poultry Science 87: 26292635. 
Wu YB, Ravindran V, Thomas DG, Birtles MJ, Hendriks WH. 2004. Influence of method of whole wheat inclusion and xylanase supplementation on the performance, apparent metabolisable energy, digestive tract measurements and gutmorphology of broilers. Poultry Science 45: 385-394.
Yamauchi K. 2002. Review on chicken intestinal villus histological alteration; related with intestinal function. The Journal of Poultry Science 39(4): 229-242. 